\title{
ANALISIS PROFIL PETERNAK TERHADAP PENDAPATAN PETERNAK BABI DI KECAMATAN LINTONG NIHUTA KABUPATEN HUMBANG HASUNDUTAN
}

\author{
(Farmer Profile Analysis of Income on Pig Farmer in Lintong Nihuta, Humbang \\ Hasundutan District)
}

\author{
Benny G. Mulya ${ }^{1}$ Hasnudi $^{2}$ dan Usman Budi ${ }^{2}$ \\ 1 Mahasiswa Program Studi Peternakan Fakultas Pertanian Universitas Sumatera Utara \\ 2 Staf Pengajar Program Studi Peternakan Fakultas Pertanian Universitas Sumatera Utara
}

\begin{abstract}
The research was conducted at the Kecamatan Lintong Nihuta, Kabupaten Humbang Hasundutan of North Sumatra, which began on 10 July to 24 August 2012. The purpose of this study was to analyze the income pig farmers, and at Humbang Hasundutan Kecamatan Lintong Nihuta. The research methods use is survey methods with a unit that maintains a family pig farmer. The sampling method used is Proportional Stratified Random Sampling is by way of selecting three village is the Desa Sigompul, Desa Hutasoit 2, Desa Nagasaribu 4. Samples from this study amounted to 60 families of pig cattle breeders obtained from $30 \%$ of farmers in each village, the Desa Sigompul (14 farmers), Desa Hutasoit 2 (21 farmers) and Desa Nagasaribu 4 (25 farmers). Based on research results obtained that business scale, farming experience, and number of dependents has a positive effect on pig cattle breeders. Where as the breeder age, educational level, and the amount of labor has a negative effect on Pig cattle breeders in the Kecamatan Lintong Nihuta Kabupaten Kabupaten Humbang Hasundutan.
\end{abstract}

Keywords : Farmer income, sampling, marketing margin

\begin{abstract}
ABSTRAK
Penelitian ini dilaksanakan di Kecamatan Lintong Nihuta, Kabupaten Humbang Hasundutan, Propinsi Sumatera Utara yang dimulai tanggal 10 Juli sampai 24 Agustus 2012. Tujuan penelitian ini adalah untuk menganalisis pengaruh profil peternak terhadap pendapatan dalam ternak babi di kecamatan Lintong Nihuta Kabupaten Humbang Hasundutan dan menghitung perbedaan harga ternak babi di peternak maupun di pasar. Metode penelitian yang digunakan adalah metode survei dengan unit responden keluarga yang memelihara ternak babi. Metode penarikan sampel yang digunakan adalah Proportional Stratified Random Sampling yaitu dengan cara memilih 3 desa yaitu Desa Sigompul, Desa Hutasoit 2, Desa Nagasaribu 4. Sampel dari penelitian ini berjumlah 60 keluarga peternak babi yang didapat dari 30\% peternak masing- masing desa, yaitu desa Sigompul (14 peternak), Desa Hutasoit 2 (21 peternak), desa Nagasaribu 4 (25 peternak). Berdasarkan hasil penelitian yang diperoleh bahwa skala usaha, pengalaman beternak, dan jumlah tanggungan keluarga berpengaruh positif terhadap peningkatan pendapatan peternak babi. Sedangkan umur peternak, tingkat pendidikan, dan jumlah tenaga kerja berpengaruh negatif terhadap pendapatan peternak babi di Kecamatan Lintong Nihuta Kabupaten Humbang Hasundutan
\end{abstract}

Kata kunci : Pendapatan, sampel, marjin pemasaran 


\section{PENDAHULUAN}

Ternak merupakan komponen penting dalam suatu sistem usaha tani di berbagai tempat di Indonesia. Walaupun kebutuhan hidup pokok bagi keluarga peternak dipenuhi oleh tanaman pangan, namun produksi ternak sering kali merupakan suatu yang penting bagi peternak untuk bisa memperoleh uang tunai, tabungan, modal, penyediaan pupuk kandang, tenaga hewan, dan merupakan bahan makanan berkualitas tinggi bagi kita ( Hardjosworo dan Levine, 1987).

Jenis Ternak yang biasa diternakkan di Indonesia adalah salah satunya ternak babi. Babi diklasifikasikan sebagai omnivora (pemakan tumbuhan dan daging) sejenis hewan yang ungulata (Hewan yang berkuku), Babi juga merupakan hewan mamalia karena menyusui anak-anaknya, dan juga hewan yang memiliki sangat banyak anak yang dilahirkan di kelas mamalia. Rata-rata babi memiliki 6 hingga 12 ekor anak setiap melahirkan.

Pemeliharaan ternak babi sama dengan ternak lainnya membutuhkan pakan yang baik. Daging sangat besar manfaatnya bagi pemenuhan gizi berupa protein dan hewani, tetapi ada juga kekurangan daging babi ini yaitu banyaknya kadar lemak didalamnya yang membuat orang kebanyakan menderita penyakit kolestrol lemak.

Pemasaran ternak babi memiliki harga yang berbeda-beda pada suatu tempat di daerah Sumatera Utara, khususnya pada daerah Lintong memiliki harga ternak babi yang cenderung tinggi, dan harga ternak di peternak dengan di pedagang pasar memiliki harga yang berbeda pula.

Masyarakat Sumatera Utara, khususnya Lintong Nihuta ternak babi sebagian besar dipelihara sebagai usaha sampingan dengan usaha pokok adalah bertani. Demikian halnya fenomena di Sumatera Utara sehingga menimbulkan pertanyaan dengan populasi ternak babi dan pemasaran harga ternak babi baik di peternak maupun di pedagang yang tidak merata.

Sehubungan dengan hal di atas maka penulis mencoba untuk meneliti dan menganalisis faktor-faktor profil peternak mempengaruhi terhadap pendapatan peternak babi pada suatu daerah berdasarkan di Kecamatan Lintong Nihuta.

Kecamatan Lintong Nihuta merupakan salah satu daerah penyebaran populasi ternak Babi di Kabupaten Humbang Hasundutan. Kabupaten Humbang Hasundutan memiliki populasi ternak babi mencapai 34.163 ekor babi dan Kecamatan Lintong Nihuta memiliki populasi sebanyak 4.702 ekor babi, Jenis babi yang banyak dijumpai di Kecamatan Lintong Nihuta adalah Duroc, Landrace, dll. 
Penyebaran populasi ternak babi, luas wilayah dan jumlah Kepala Keluarga (KK) di Kecamatan Lintong Nihuta menurut desa tersaji pada Tabel 1.

Tabel 1. Luas wilayah, Jumlah KK, dan Populasi ternak babi di kecamatan Lintong Nihuta menurut desa.

\begin{tabular}{clrcc}
\hline No. Nama Desa & \multicolumn{2}{c}{$\begin{array}{c}\text { Luas wilayah } \\
\text { (Ha) }\end{array}$} & $\begin{array}{c}\text { Populasi } \\
\text { Ternak Babi } \\
\text { (Ekor) }\end{array}$ & $\begin{array}{c}\text { Kepadatan } \\
\text { Per } \\
\text { Ekor }\end{array}$ \\
\hline 1 & Hutasoit I & 940,08 & 168 & 0,18 \\
2 & Lobutua & 867,32 & 163 & 0,19 \\
3 & Pargaulan & 780,59 & 182 & 0,23 \\
4 & Nagasaribu I & 689,13 & 179 & 0,26 \\
5 & Nagasaribu II & 725,40 & 177 & 0,24 \\
6 & Siharjulu & 1235,03 & 225 & 0,18 \\
7 & Sibuntuon Parpea & 630,78 & 213 & 0,34 \\
8 & Sibuntuon & 502,25 & 224 & 0,45 \\
9 & Sitolu Bahal & 1031 & 219 & 0,21 \\
10 & Tapian Nauli & 1576,96 & 217 & 0,14 \\
11 & Siponjot & 632,88 & 228 & 0,36 \\
12 & Dolok Margu & 1261,77 & 203 & 0,16 \\
13 & Sitio II & 541,13 & 214 & 0,40 \\
14 & Hutasoit II & 729,54 & 153 & 0,21 \\
15 & Bonan Dolok & 709,64 & 164 & 0,23 \\
16 & Sigompul & 638,67 & 292 & 0,46 \\
17 & Nagasaribu IV & 688,58 & 395 & 0,57 \\
18 & Nagasaribu V & 617,15 & 215 & 0,35 \\
19 & Nagasaribu III & 906,75 & 207 & 0,23 \\
20 & Sigumpar & 972,72 & 187 & 0,19 \\
21 & Parulohon & 761,32 & 246 & 0,32 \\
22 & Habeahan & 687,34 & 111 & 0,16 \\
& JUMLAH & 18126,03 & 6314 & 0,22 \\
\hline
\end{tabular}

Sumber : Badan Pusat Statistik, 2011

\section{BAHAN DAN METODE}

\section{Lokasi dan Waktu Penelitian}

Penelitian dilaksanakan di Kecamatan Lintong Nihuta Kabupaten Humbang Hasundutan. Penelitian dilaksanakan 1 bulan sekitar bulan Juli 2012.

\section{Metode Penentuan Responden Penelitian}

Responden terdiri dari para peternak babi dan para pedagang di pasar Kecamatan Lintong Nihuta, Kabupaten Humbang Hasundutan. Metode responden yang digunakan adalah metode survei dengan unit analisis keluarga yang memelihara ternak babi dan pedagang di pasar . Metode penarikan responden yang digunakan adalah sebagai berikut :

1. Pada tahap pertama pemilihan 3 desa dari beberapa desa yang ada di Kecamatan Lintong Nihuta yaitu : Desa Nagasaribu IV, Sigompul dan 
Hutasoit II dengan metode penarikan responden secara Proportional Stratified Random Sampling menurut Wirartha, (2006).

2. Pada tahap kedua pemilihan responden secara acak sederhana, diambil masing-masing minimal 30 peternak babi dari setiap desa sampel, tetapi jika kurang dari 30 peternak babi dari setiap desa, maka harus diambil semua.

3. Pada tahap ketiga memilih peternak dan pedagang babi di pasar kecamatan lintong nihuta kabupaten humbang hasundutan, agar mengetahui rata-rata perbedaan harga di pedagang dengan peternak.

\section{Pengumpulan Data}

Data yang dikumpulkan dalam penelitian ini terdiri dari data Primer maupun sekunder,

1. Data primer diperoleh dari monitoring terhadap kegiatan usaha ternak babi melalui wawancara dan pengisian kuesioner,

2. Data sekunder diperoleh dari berbagai instansi yang terkait seperti Bada1 Statistik Medan, Kantor Kecamatan Lintong Nihuta.

\section{Metode Analisis Data}

Data yang diperoleh dari hasil wawancara responden di lapangan yang diolah dan ditabulasikan, kemudian data dianalisis dengan menggunakan metode analisis sosial ekonomi dapat diolah dengan menggunakan model pendekatan ekonometri dan dijelaskan secara deskriptif. Menurut Soekartawi (1995), untuk menghitung keuntungan atau total pendapatan dari kegiatan beternak babi dapat dihitung sebagai berikut :

$$
\mathrm{Pd}=\mathrm{TR}-\mathrm{TC}
$$

Keterangan :

$\mathrm{Pd}=$ Total keuntungan yang diperoleh peternak babi (Rupiah/tahun)

$\mathrm{TR}=$ Total revenue atau penerimaan (Rupiah/tahun)

$\mathrm{TC}=$ Total cost atau pengeluaran yang dikeluarkan oleh peternak babi (Rupiah/tahun)

Berdasarkan hasil yang diperoleh, maka untuk memperoleh faktor profil peternak yang mempengaruhi pendapatan dapat dilihat dengan menggunakan metode pendekatan teknik Ekonometri dengan analisis Regresi Linear Berganda (Alat bantu software seperti SPSS 17).

Menurut Djalal dan Usman (2002), model pendugaan yang digunakan adalah :

$$
\ddot{Y}=a+b_{1} X_{1}+b_{2} X_{2}+b_{3} X_{3}+b_{4} X_{4}+b_{5} X_{5}+b_{6} X_{6}+\mu
$$




\section{Keterangan :}

$\begin{array}{ll}\ddot{\mathrm{Y}} & =\text { pendapatan peternak ( rupiah) } \\ \mathrm{a} & =\text { koefisien intercept (konstanta) } \\ \mathrm{b}_{1,2,3,4,5,6} & =\text { koefisien regresi } \\ \mathrm{X}_{1} & =\text { skala usaha (jumlah ternak babi) } \\ \mathrm{X}_{2} & =\text { umur peternak (tahun) } \\ \mathrm{X}_{3} & =\text { tingkat pendidikan (tahun) } \\ \mathrm{X}_{4} & =\text { pengalaman beternak (tahun) } \\ \mathrm{X}_{5} & =\text { jumlah tanggungan keluarga (jiwa) } \\ \mathrm{X}_{6} & =\text { jumlah tenaga kerja (jiwa) } \\ \mu & =\text { variabel lain yang tidak diteliti }\end{array}$

Variabel-variabel pada hipotesis diuji serempak dan parsial untuk mengetahui apakah variabel tersebut memiliki dominan atau tidak. Jika variabel tersebut berpengaruh secara serempak maka digunakan dengan uji $\mathrm{F}$ yakni :

$$
\mathrm{F}=\frac{\mathrm{r}^{2} / \mathrm{k}}{\left(1-\mathrm{r}^{2}\right) /(\mathrm{n}-\mathrm{k}-1)}
$$

Keterangan :

$$
\begin{array}{ll}
\mathrm{r}^{2} & =\text { Koefisien determinasi } \\
\mathrm{n} & =\text { Jumlah responden } \\
\mathrm{k} & =\text { Derajat bebas pembilang } \\
\mathrm{n}-\mathrm{k}-1 & =\text { Derajat bebas penyebut }
\end{array}
$$

Kriteria uji :

$\mathrm{F}$ hitung $\leq \mathrm{F}$ tabel. H0 diterima (H1 ditolak)

F hitung $>$ F tabel. H0 ditolak (H1 diterima)

Menurut Sudjana (2002), jika variabel berpengaruh secara parsial, maka dapat diuji:

$$
\mathrm{T}_{\text {hit }}=\underline{\mathrm{b}}_{1}
$$$$
\mathrm{S}^{2} \mathrm{y}_{123}=\frac{\sum(-\mathrm{y})^{2}}{\mathrm{n}-\mathrm{k}-1}
$$

$$
\mathrm{S}^{2} \mathrm{~b}_{1}=\sqrt{\frac{s^{2} y_{1234}}{\sum X i^{2}\left(1-r^{2}\right)}}
$$

Keterangan :

b

$\mathrm{n}-\mathrm{k}-1$

$$
=\text { Parameter }(i=1,2,3,4)
$$

$=$ Derajat bebas

$\mathrm{S}^{2} \mathrm{~b}_{1} \quad=$ Standard eror parameter $\mathrm{b}$

$\mathrm{S}^{2} \mathrm{y}_{1234}$

$=$ Standard eror estimates

$\mathrm{X}_{\mathrm{i}}$

$$
=\text { Variabel bebas }(i=1,2,3,4)
$$

Kriteria uji :

F-hit $\leq$ F-tabel. H0 diterima (H1 ditolak)

F-hit $>$ F-tabel H0 ditolak (H1 diterima) 


\section{Marjin Pemasaran}

Pada pemasaran ternak babi di daerah penelitian yaitu pemasaran berat bobot hidup yang terdiri dari pemasaran anakan dan indukan, tetapi memiliki perbedaan. Pemasaran anakan memperhitungkan harga per ekor nya tanpa memperhitungkan bobot kilogram ternak, tetapi pemasaran indukan memperhitungkan per kilogram bobot badannya.

Marjin pemasaran anakan dirumuskan dengan cara menghitung perbedaan antara harga di tingkat Pasar dengan harga di tingkat Peternak. Marjin Pemasaran dalam penelitian ini di rumuskan sesuai petunjuk Sudiyono (2002) sebagai berikut:

$\mathrm{M}=\mathrm{He}-\mathrm{Hp}$

Keterangan :

$\mathrm{He}=$ Harga pada pasar $(\mathrm{Rp} .$. /ekor $)$

$\mathrm{Hp}=$ Harga pada peternak (Rp.../ekor)

Marjin pemasaran indukan dirumuskan dengan cara menghitung perbedaan antara $h$ di tingkat Pasar dengan harga di tingkat Peternak. Marjin Pemasaran dalam penelitian ini di rumuskan sesuai petunjuk Sudiyono (2002) sebagai berikut:

$\mathrm{M}=\mathrm{He}-\mathrm{Hp}$

Keterangan :

$\mathrm{He}=$ Harga pada pasar $(\mathrm{Rp} \ldots / \mathrm{Kg})$

$\mathrm{Hp}=$ Harga peternak $(\mathrm{Rp} . . . / \mathrm{Kg})$

\section{Parameter Penelitian}

\section{Analisis Pendapatan}

1. Skala usaha adalah jumlah ternak babi yang dipelihara (ekor),

2. Umur peternak yang memelihara ternak babi (tahun)

3. Tingkat pendidikan adalah lama pendidikan yang ditempuh peternak ( tahun),

4. Pengalaman beternak adalah lamanya peternak dalam memelihara ternak babi tahun),

5. Jumlah tanggungan keluarga adalah jumlah tanggungan yang ditanggung peternc dalam satu keluarga ( jiwa),

6. Jumlah tenaga kerja adalah Jumlah suatu tenaga kerja dalam keluarga atau upahan yang dibiayai oleh peternak (jiwa).

Marjin Pemasaran Ternak Babi :

1. Harga pasar adalah Harga jual ternak indukan dan anakan yang ditawarkan oleh pasar kepada konsumen (Pola 1), 
2. Harga peternak adalah Harga jual ternak indukan dan anakan yang ditawarkan oleh peternak kepada konsumen (Pola 2).

\section{HASIL DAN PEMBAHASAN}

\section{Karakteristik Responden}

Masyarakat di Kecamatan Lintong Nihuta cenderung menjadikan usaha ternak babi sebagai usaha sampingan sehingga hanya memberikan kontribusi dibawah 30\% terhadap pendapatan peternak. Masyarakat di Kecamatan Lintong Nihuta pada umumnya bermata pencaharian sebagai petani, sehingga pendapatan mereka berasal dari hasil-hasil pertanian. Karakteristik responden di daerah penelitian dapat dilihat pada Tabel 2.

Tabel 2. Karakteristik responden di daerah Lintong Nihuta tahun 2012

\begin{tabular}{lccr}
\hline Karakteristik peternak Babi & satuan & Rentang $\left(^{*}\right)$ & \multicolumn{1}{c}{ Rataan } \\
\hline Skala usaha & Ekor & $5-33$ & 11 \\
Umur peternak & Tahun & $29-59$ & 48 \\
Tingkat pendidikan & Tahun & $6-12$ & 12 \\
Pengalaman beternak & Tahun & $2-10$ & 5 \\
Jumlah Tanggungan Keluarga & Jiwa & $5-9$ & 6 \\
Jumlah tenaga kerja & Jiwa & $1-4$ & 3 \\
Total penerimaan dari usaha & Rp & $7.290 .000-25.200 .000$ & $12.281 .416,67$ \\
ternak & & & \\
Total biaya pengeluaran & Rp & $3.053 .000-23.494 .000$ & 9.158 .100 \\
Pendapatan bersih usaha & Rp & $570.000-4.929 .000$ & $3.123 .316,67$ \\
ternak & & & \\
\hline
\end{tabular}

Sumber : Data Primer Penelitian (2012)

Karakteristik responden dalam penelitian ini meliputi karakteristik sosial dan ekonomi. Karakteristik sosial peternak yang dianalisis meliputi skala usaha, umur peternak, tingkat pendidikan, pengalaman beternak, jumlah tanggungan keluarga, dan jumlah tenaga kerja. Sedangkan karakteristik ekonomi responden yang dianalisis meliputi: total penerimaan dari usaha ternak dan total biaya pengeluaran, sedangkan untuk karakteristik marjin pemasaran dapat dilihat pada Tabel 3.

Karakteristik pada marjin pemasaran yang diteliti di Kecamatan Lintong Nihuta adalah jumlah pedagang, rata-rata jumlah anakan hidup yang diperjualkan oleh pedagang, rata-rata harga jual anakan oleh pedagang, rata-rata jumlah indukan hidup yang diperjualkan oleh pedagang, rata-rata harga jual indukan oleh pedagang, rata-rata jumlah anakan hidup yang diperjualkan oleh peternak, rata-rata harga jual anakan oleh peternak, rata-rata jumlah indukan hidup yang diperjualkan oleh peternak, rata-rata harga jual indukan oleh peternak, 
rata-rata marjin pemasaran anakan, dan rata-rata marjin pemasaran indukan.Skala usaha beternak babi menyebar antara 5 sampai 33 ekor dengan rataan 11 ekor.

Berdasarkan data tersebut dapat dikatakan bahwa jumlah kepemilikan ternak babi dalam usaha beternak babi cendrung sedikit (Tohir,1991). Umur peternak menyebar antara 29 sampai 59 tahun dengan rataan 48 tahun. Hal ini menunujukan bahwa responden sudah berada dalam kategori umur kurang produktif (20 sampai 45 tahun), sehingga potensi untuk bekerja dan mengelola usaha ternaknya masih besar (Chamdi, 2003).

Tabel 3. Karakteristik Marjin Pemasaran didaerah Lintong Nihuta

\begin{tabular}{|c|c|c|c|}
\hline Karakteristik peternak sampel & Satuan & Rentang $(*)$ & Rataan \\
\hline $\begin{array}{l}\text { Jumlah peternak dan } \\
\text { pedagang }\end{array}$ & Jiwa & - & 14 \\
\hline $\begin{array}{l}\text { Rata-rata jumlah ternak } \\
\text { anakan hidup yang } \\
\text { diperjualkan oleh pedagang }\end{array}$ & Ekor & $3-5$ & 4 \\
\hline $\begin{array}{l}\text { Rata-rata harga jual anakan } \\
\text { oleh pedagang }\end{array}$ & $\mathrm{Rp}$ & $615000-650000$ & 635.000 \\
\hline $\begin{array}{l}\text { Rata-rata jumlah ternak } \\
\text { indukan hidup yang } \\
\text { diperjualkan oleh pedagang }\end{array}$ & Ekor & $2-5$ & 3 \\
\hline $\begin{array}{l}\text { Rata-rata harga jual indukan } \\
\text { oleh pedagang }\end{array}$ & $\mathrm{Rp} / \mathrm{Kg}$ & $32000-35000$ & 32.750 \\
\hline $\begin{array}{l}\text { Rata-rata jumlah ternak } \\
\text { anakan hidup yang } \\
\text { diperjualkan oleh peternak }\end{array}$ & Ekor & $6-10$ & 8 \\
\hline $\begin{array}{l}\text { Rata-rata harga jual anakan } \\
\text { oleh peternak }\end{array}$ & $\mathrm{Rp}$ & $500000-600000$ & 576.000 \\
\hline $\begin{array}{l}\text { Rata-rata jumlah ternak } \\
\text { indukan hidup yang } \\
\text { diperjualkan oleh peternak } \\
\text { Rata-rata harga jual indukan } \\
\text { oleh peternak }\end{array}$ & $\mathrm{Rp} / \mathrm{Kg}$ & $26000-29000$ & 27.400 \\
\hline $\begin{array}{l}\text { Rata-rata marjin pemasaran } \\
\text { anakan }\end{array}$ & $\mathrm{Rp}$ & - & 59.000 \\
\hline $\begin{array}{l}\text { Rata-rata marjin pemasaran } \\
\text { Indukan }\end{array}$ & $\mathrm{Rp} / \mathrm{Kg}$ & - & 5.350 \\
\hline
\end{tabular}


Pengalaman beternak babi menyebar antara 2 sampai 10 tahun dengan rataan 5 tahun. Berdasarkan data tersebut dapat dikatakan bahwa tingkat pengalaman beternak responden cukup lama, tetapi kurang menguasai tentang teknik pengelolaan usaha ternaknya (Wiryono, 1997).

Tingkat pendidikan peternak babi menyebar antara 6 sampai 12 tahun dengan rataan 12 tahun. Hal ini menunjukan bahwa tingkat pendidikan responden rata-rata sudah tamat SMA, sehingga tingkat pendidikan responden digolongkan rendah. Pendidikan non formal di daerah penelitian yang khusus mengenai usaha ternak babi tidak begitu berjalan dengan baik (Fauzia dan Tampubolon, 1991).

Jumlah tenaga kerja menyebar antara 1 sampai 4 orang dengan rataan 4 orang. Hal ini menunujukan bahwa responden memiliki tenaga kerja yang cukup untuk beternak babi (Soekartawi, 1995).

Jumlah tanggungan keluarga menyebar antara 4 sampai 9 orang dengan rataan $\epsilon$ orang, Hal ini menunjukkan bahwa di dalam keluarga tersebut cukup banyak (Daniel, 2002).

Pada usaha ternak babi di daerah penelitian diperoleh total penerimaan dari usaha ternak babi selama 1 (satu) tahun adalah berkisar antara Rp 7.290.000 sampai dengan $\mathrm{Rp}$ 25.200.000 / peternak dengan rataan sebesar Rp. 12.281.416,67 / peternak.

Total biaya pengeluaran pada usaha ternak babi meliputi biaya pakan, obat-obatan, tenaga kerja, dan biaya lainnya .Menurut data yang diperoleh selama 1 (satu) tahun dari usaha ternak babi per responden adalah berkisar antara Rp. 3.053 .000 / peternak sampai dengan Rp 19.260.000 /peternak dengan nilai pengeluaran rata-rata adalah Rp. 9.158.100/peternak.

Pendapatan bersih setiap responden dari usaha ternak babi selama 1 (satu) tahun berkisar antara Rp 570.000 sampai dengan Rp 6.400 .000 dengan rataan sebesar Rp. 3.123.316,67,- /peternak. Dari nilai rata-rata pendapatan keluarga dari usaha ternak babi ini dapat digambarkan bahwa responden kurang termotivasi untuk melakukan pengembangan usaha ternak babi nya, Mereka belum melihat dengan baik bahwa ternak babi yang mereka usahakan ini dapat mendatangkan pendapatan yang lebih besar lagi apabila dilakukan dengan serius.

Biaya lain-lain yang dikeluarkan oleh peternak untuk usaha ternak mencakup biaya perbaikan kandang, biaya pembelian peralatan pendukung usaha ternak seperti kereta so (angkong), cangkul, sapu lidi, dan biaya bahan bakar. 
Rataan jumlah pedagang babi di daerah penelitian sebanyak 14 orang, ratac akan hidup yang dijual oleh pedagang sebanyak 4 ekor, rataan jumlah anakan hidup yang dijual oleh peternak sebanyak 8 ekor, rataan harga jual anakan oleh pedagang sebesar Rp. 635.000,, rataan harga jual anakan oleh peternak sebesar Rp. 576.000,- , rataan jumlah indukan hidup yang dijual pedagang sebesar

3 ekor, rataan jumlah indukan hidup yang dijual peternak sebesar 2 ekor, rataan harga jual indukan oleh pedagang sebesar Rp. 32.750,- /Kg, rataan harga jual indukan oleh peternak sebesar Rp. 27.400,- /Kg, rataan marjin pemasaran anakan sebesar Rp 59.000, dan r ata marjin pemasaran indukan sebesar Rp. 5.350,-/Kg.

\section{Pengaruh Variabel terhadap Pendapatan Peternak Babi}

Faktor-faktor profil peternak yang mempengaruhi pendapatan peternak babi di Kecamatan Lintong Nihuta Kabupaten Humbang Hasundutan diuji dengan analisis regresi linier berganda dengan variabel bebas (independent) adalah skala usaha $\left(\mathrm{X}_{1}\right)$, umur peternak $\left(\mathrm{X}_{2}\right)$, tingkat pendidikan $\left(\mathrm{X}_{3}\right)$ dan pengalaman beternak $\left(\mathrm{X}_{4}\right)$, jumlah tanggungan keluarga $\left(\mathrm{X}_{5}\right)$, jumlah tenaga kerja $\left(\mathrm{X}_{6}\right)$, sedangkan yang menjadi variabel terikat (dependent) adal $i^{-1}$ pendapatan (Y) dapat dilihat pada Tabel 4.

Tabel 4. Analisis regresi linier berganda pendapatan peternak babi di Kecamatan Lintong Nihuta, Kabupaten Humbang Hasundutan

\begin{tabular}{crrrr} 
Variabel & Koefisien Regresi & \multicolumn{1}{c}{ Std. Error } & t- hitung & Signifikan \\
\hline Konstanta & 9.060 .648 & $6.341 .444,6$ & 1,429 & 0,159 \\
X1 & $96.390,03$ & $4.278 .431,6$ & 0,023 & 0,982 \\
X2 & $-47.108,1$ & $30.665,015$ & $-1,536$ & 0,130 \\
X3 & -459.757 & $539.555,5$ & $-0,852$ & 0,398 \\
X4 & $365.091,5$ & $140.599,6$ & 2,597 & 0,012 \\
X5 & $135.339,4$ & $162.054,9$ & 0,835 & 0,407 \\
X6 & -271.323 & $335.496,2$ & $-0,809$ & 0,422 \\
R square & 0,189 & & & \\
Regresion & $1,9 \mathrm{E}+13$ & & & \\
Residual & $8,4 \mathrm{E}+13$ & & & \\
F-tabel & 2,436 & & & \\
$(\alpha=0,05)$ & & & & \\
T-tabel $(\alpha=0,05)$ & 2,029 & & &
\end{tabular}

Berdasarkan Hasil Regresi di atas dapat diketahui:

Nilai Konstanta/Intersept adalah sebesar 9.060.648, Artinya apabila variabel bebas yaitu skala usaha, umur peternak, pengalaman beternak, tingkat pendidikan, jumlah tanggungan 
keluarga, dan jumlah tenaga kerja dilakukan maka peternak babi akan menerima pendapatan sebesar nilai konstanta yaitu Rp 9.060.648/tahun.

1. R Square bernilai $18,9 \%$, artinya bahwa semua variabel profil peternak babi dapat mempengaruhi pendapatan peternak babi sebesar 18,9\% dan selebihnya yaitu sebesar $81,1 \%$ dijelaskan oleh variabel yang tidak diteliti dalam penelitian ini.

2. Secara serempak nilai F-hitung $(2,054)$ lebih kecil daripada F-tabel $(2,436)$. Hal ini menunjukkan bahwa secara serempak semua variabel tersebut yaitu skala usaha, umur peternak, tingkat pendidikan, jumlah tanggungan keluarga, jumlah tenaga kerja berpengaruh tidak nyata terhadap pendapatan peternak babi dengan taraf signifikansi $0.075^{\mathrm{a}}$ dan pada taraf kepercayaan $95 \%$.

3. Secara partial nilai t-hitung variabel yang mempengaruhi adalah variabel skala usána $(0,023)$, umur peternak $(-1,536)$, tingkat pendidikan (-0.852), pengalaman beternak (2.597), jumlah tanggungan keluarga (0.835), jumlah tenaga kerja (-0.809).

a. Variabel skala usaha berpengaruh tidak nyata terhadap pendapatan karena nilai signifikan skala usaha 0,982>0,05, jika diukur pada tingkat kepercayaan 95\%. dan angka koefisien 96.390,03. Sifat hubungan dari koefisien regresi bertanda pus berarti setiap kenaikan umur sebesar 1 ekor, maka mengalami kenaikan sebesar Rp. 96.390,03,- dari pendapatan peternak. Hal ini sesuai pernyataan Tohir (1991) bahwa skala usaha memberikan keuntungan pada peternak, semakin banyak ternak yang dimiliki peternak, makin besar keuntungan dan menaikkan pendapatan peternak.

b. Variabel umur berpengaruh tidak nyata terhadap pendapatan,karena nilai signifikan umur 0,13>0,05, jika diukur pada tingkat kepercayaan 95\%, dan angka koefisien 47.108,1. Sifat hubungan dari koefisien regresi bertanda negatif, berarti setian kenaikan umur sebesar 1 tahun maka akan menurunkan pendapatan peternan sebesar Rp 47.108,1 Faktor umur biasanya lebih diidentikkan dengan produktivitas kerja, dan jika seseorang masih tergolong usia produktif ada kecenderungan produktivitasnya juga tinggi. Chamdi (2003) mengemukakan, semakin muda usia peternak (usia produktif 20-45 tahun) umumnya rasa ingin tahu terhadap sesuatu semakin tinggi dan minat untuk mengadopsikan terhadap introduksi teknologi semakin tinggi.

c. Variabel tingkat pendidikan berpengaruh tidak nyata terhadap pendapatan, karena nilai signifikan tingkat pendidikan $0,398>0,05$ jika diukur pada tingkat kepercayaan 95\% dan memiliki koefisien 459.757, Koefisien tersebut menunjukkan 
bahwa kenaikan tingkat pendidikan peternak sebesar 1 tahun maka akan diikuti kenaikan peternak sebesar Rp 459.757,-. Hal ini sesuai dengan pernyataan Wiryono (1997), yang menyatakan bahwa tingkat pendidikan peternak lebih cenderung mempengaruhi cara berpikir dan tingkat penerimaan mereka terhadap inovasi dan pada teknologi baru.

d. Variabel pengalaman beternak berpengaruh nyata terhadap pendapatan karena nilai signifikan pengalaman $0,012<0,05$ jika diukur pada tingkat kepercayaan 95\% dan angka koefisien 365.091,5 Sifat hubungan dari koefisien regresi bertanda positif maka dapat diasumsikan bahwa kenaikan pengalaman peternak sebesar 1 tahun maka akan diikuti kenaikan pendapatan peternak sebesar Rp.365.091.5,-. faktor pengalaman yang dimiliki peternak masyarakat sangat menentukan pula berkembangnya peternakan di daerah itu (Fauzia dan Tampubolon, 1991).Hal ini disebabkan bahwa dengan pengalaman beternak yang cukup lama memt ${ }^{-1}$ in indikasi bahwa pengetahuan dan keterampilan peternak terhadap manajemen pemeliharaan ternak mempunyai kemampuan yang lebih baik.

e. Variabel jumlah tanggungan keluarga berpengaruh tidak nyata terhadap pendapatan karena nilai signifikan jumlah tanggungan keluarga 0,407 >0,05 jika diukur pada tingkat kepercayaan 95\%, dan nilai koefisien 135.339,4. Sifat hubungan dari koefisien regresi bertanda positif, maka dapat diasumsikan bahwa kenaikan jumlah tanggungan keluarga sebesar 1 jiwa, maka akan diikuti kenaikan pendapatan peternak sebesar Rp.135.339,4,-. Hal ini sesuai pernyataan Daniel (2002) menyatakan dengan pertambahan anggota secara terus-menerus, sementara kebutuhan akan diproduksi termasuk pangan semakin bertambah, tetapi hal ini tidak terjadi di lapangan karena $\mathrm{p}$ nak tersebut menjual banyak hasil pertanian dan perkebunan, oleh karena itu mereka mengeluarkan sedikit pendapatan mereka kepada keluarga karena hasil kebutuhan pokok mereka banyak terdapat di tempat, seperti padi, kopi, sayur-sayuran, dll yang mereka jadikan bahan pokok peternak tersebut. Dengan kata lain, peternak dapat menaikkan pendapatan mereka.

f. Variabel jumlah tenaga kerja berpengaruh tidak nyata terhadap pendapatan karena nilai signifikan jumlah tenaga kerja 0,422 >0,05 jika diukur tingkat kepercayaan 95\% dan nilai koefisien - 271.323. Sifat hubungan dari koefisien regresi bertanda negatif, maka dapat diasumsikan bahwa kenaikan jumlah tenaga kerja sebesar 1 jiwa dengan asumsi variabel lain diikuti penurunan pendapatan peternak sebesar Rp. 
271.323,-. Hal ini disebabkan bahwa tenaga kerja memerlukan biaya lain-lain untuk dirinya, sehingga mengurangi pendapatan peternak. Hal ini menurut pernyataan Soekartawi (1995) bahwa pendapatan keluarga peternak tidak dapat dilepaskan dengan cara mereka menjalankan dan mengelola usaha ternaknya sangat dipengaruhi oleh beberapa faktor sosial dan ekonomi.

Berdasarkan hasil penelitian, diperoleh persamaan linear berganda sebagai berikut

$$
\begin{aligned}
\hat{\mathbf{Y}}= & 9.060 .648+96.390,03 \mathbf{X}_{\mathbf{1}}-47.108,1 \mathbf{X}_{\mathbf{2}}+459.757 \mathbf{X}_{\mathbf{3}}+365.091,5 \mathbf{X}_{\mathbf{4}}+ \\
& 135.339,4 \mathbf{X}_{\mathbf{5}}-271.323 \mathbf{X}_{\mathbf{6}}+\mu
\end{aligned}
$$

Berdasarkan model persamaan diatas dapat disimpulkan bahwa:

a. Apabila variabel bebas skala usaha $\left(\mathrm{X}_{1}\right)$ mengalami kenaikan sebesar 1 ekor, maka akan terjadi kenaikan pendapatan (Y) sebesar Rp. 96.390,03,-.

b. Apabila variabel bebas umur $\left(\mathrm{X}_{2}\right)$ mengalami kenaikan sebesar 1 tahun, maka akan terjadi penurunan pendapatan (Y) sebesar Rp. 47.108,1,-.

c. Apabila variabel bebas pendidikan $\left(\mathrm{X}_{3}\right)$ mengalami kenaikan sebesar 1 tahun maka akan terjadi kenaikan pendapatan (Y) sebesar Rp. 459.757,-.

d. Apabila variabel bebas pengalaman beternak $\left(\mathrm{X}_{4}\right)$ mengalami kenaikan sebesar 1 tahun, maka akan terjadi kenaikan pendapatan (Y) sebesar Rp. 365.091,5,--

e. Apabila variabel bebas jumlah tanggungan keluarga (X5) mengalami kenaikan 1 jiwa, maka akan terjadi kenaikan pendapatan (Y) sebesar Rp. 135.339,4,-.

f. Apabila variabel bebas jumlah tenaga kerja $\left(\mathrm{X}_{6}\right)$ mengalami kenaikan 1 jiwa , maka akan terjadi penurunan pendapatan (Y) sebesar Rp. 271.323,--.

g. Apabila variabel $\mathrm{X}_{1}, \mathrm{X}_{2}, \mathrm{X}_{3}, \mathrm{X}_{4}, \mathrm{X}_{5}$ dan $\mathrm{X}_{6}$ yang dianalisis dianggap nol, maka peternak babi akan menanggung biaya sebesar Rp 9.060.648 /tahun.

\section{KESIMPULAN}

Berdasarkan hasil penelitian analisis profil peternak terhadap pendapatan dan marjin pemasaran peternak babi di Kecamatan Lintong Nihuta Kabupaten Humbang Hasundutan dapat disimpulkan sebagai berikut :

1. Skala usaha, Pengalaman beternak, dan Jumlah tanggungan keluarga dapat menaikkan pendapatan di Kecamatan Lintong Nihuta Kabupaten Humbang Hasundutan.

2. Umur peternak, Pendidikan peternak, dan jumlah tenaga kerja dapat menurunkan pendapatan di Kecamatan Lintong Nihuta Kabupaten Humbang Hasundutan. 
3. Rata-rata marjin pemasaran anakan memiliki rentangan $\mathrm{Rp} 59.000$, dan rata-rata marjin pemasaran indukan memiliki rentangan $\mathrm{Rp} 5.350,-/ \mathrm{Kg}$.

\section{DAFTAR PUSTAKA}

Chamdi, A.N, 2003. Kajian Profil Sosial Ekonomi Usaha Babi di Kecamatan Kradenan Kabupaten Grobongan. Prosiding Seminar Nasional Teknologi Peternakan dan Veteriner. Bogor 29-30 September 2003. Puslitbang Peternakan Departemen Pertanian, Bogor.

Daniel, M, 2002. Pengantar Ekonomi Pertanian. Bumi Aksara, Jakarta.

Djalal dan Usman. 2002. Analisis Ekonometri. Penerbit Kasuari, Semarang.

Fauzia, dan Tampubolon, 1991., Pengaruh Keadaan Sosial Ekonomi Petani Terhadap Keputusan Petani Dalam Penggunaan Sarana Produksi. USU Press. Medan.

Hardjosworo, P.S., dan J.M. Levine, 1987., Pengembangan Peternakan di Indonesia. Yayasan Obor Indonesia. Jakarta.

Soekartawi, 1995. Analisis Usaha Tani. UI Press. Jakarta.

Sudiyono, 2002.Ternak Babi. Penebar Swadaya, Jakarta.

Tohir, K. A, 1991. Pengantar Ekonomi Pertanian. Penerbit Sumur Bandung. Bandung. Wirartha,I. Made. 2006. Metodologi Penelitian Sosial Ekonomi. Penerbit Andi. Yogyakarta. Wiryono, 1997. Sosial Ekonomi Beternak Babi. Penerbit Swadaya. Jakarta. 